\title{
Fourier Transform Infrared Spectroscopy (FTIR) for MUN analysis in normal and adulterated Milk
}

\author{
[Espectroscopia no Infravermelho em Transformada Fourier para a análise de ureia \\ em leite normal e adulterado] \\ M.C.P.P. Oliveira, N.M.A. Silva, L.P.F. Bastos, L.M. Fonseca*, M.M.O.P. Cerqueira, \\ M.O. Leite, R.S. Conrrado
}

Escola de Veterinária - Universidade Federal de Minas Gerais - Belo Horizonte, MG

\begin{abstract}
The objective of this study was to evaluate the CombiScope FTIR equipment based on Fourier Transform Infrared methodology (FTIR), to assess the content of milk urea nitrogen (MUN) in Brazil. Repeatability and reproducibility of CombiScope ${ }^{\mathrm{TM}}$ FTIR (Delta Instruments), and comparison with an enzymatic automated method (Chemspec ${ }^{\circledR} 150$; Bentley Instruments) were tested to measure raw milk urea nitrogen (MUN). Additionally, MUN levels stability after storage of raw milk samples at $4{ }^{\circ} \mathrm{C}$, and $20^{\circ} \mathrm{C}$ for up to 15 days, and capability and precision to detect extraneous urea added as an adulterant to the milk were evaluated by FTIR equipment. There was a high correlation coefficient for the analysis of MUN by FTIR equipment, when compared with the automated enzymatic method, with no significant difference between both. MUN concentration in raw milk remained stable at temperatures of $4^{\circ} \mathrm{C}$ for up to 15 days of storage, but after 3 days of storage at $20^{\circ} \mathrm{C}$ there was an increase in the MUN levels. The CombiScope FTIR equipment proved to be a reliable method for analysis of MUN content in raw milk. However, results for MUN were not linear with the amount of extraneous urea added to raw milk, having a significant difference for samples when $40 \mathrm{mg} / \mathrm{dL}$ of urea was added to milk.
\end{abstract}

Keywords: milk, validation, milk urea nitrogen, infrared spectroscopy, FTIR

\section{RESUMO}

O objetivo deste estudo foi realizar a avaliação do CombiScope ${ }^{\mathrm{TM}}$ FTIR (Delta Instruments), um equipamento baseado na espectroscopia de infravermelho por metodologia em Transformada Fourier (FTIR) para a avaliação do teor de nitrogênio uréico no leite (NUL) cru produzido no Brasil. A repetibilidade e reprodutibilidade do CombiScope ${ }^{\mathrm{TM}}$ FTIR (Delta Instruments) e a comparação com um método enzimático automatizado (ChemSpec ${ }^{\circledR}$ 150; Bentley Instruments) foram testados para a medição do nitrogênio uréico no leite (NUL) cru. Adicionalmente, os níveis de NUL após armazenamento das amostras de leite $a 4^{\circ} \mathrm{C}$ e $20^{\circ} \mathrm{C}$ por até 15 dias, e a capacidade e precisão para detectar uréia adicionada de forma fraudulenta ao leite foram avaliados por FTIR. Houve alta correlação entre os métodos FTIR $e$ enzimático automatizado para a análise de uréia, sem diferença significativa entre ambos $(p>0,05)$. A concentração de uréia no leite cru manteve-se estável durante o armazenamento das amostras a $4^{\circ} \mathrm{C}$ por até 15 dias. No entanto, após três dias à temperatura de $20^{\circ} \mathrm{C}$ houve um aumento nos níveis de uréia. Os resultados obtidos evidenciam que o equipamento CombiScope ${ }^{\mathrm{TM}}$ FTIR é um método confiável para a análise do teor de uréia no leite cru. Entretanto, a detecção de uréia adicionada de forma fraudulenta ao leite cru não foi linearmente proporcional, com diferença significativa para adição de uréia em níveis de $40 \mathrm{mg} / \mathrm{dL}$.

Palavras-chave: leite, validação, nitrogênio uréico no leite, espectroscopia no infravermelho, FTIR

Recebido em 3 de março de 2012

Aceito em 23 de agosto de 2012

*Autor para correspondência (corresponding author)

E-mail: leorges@ufmg.br 


\section{INTRODUCTION}

Urea or milk urea nitrogen (MUN) is a nonprotein component of milk. Non-protein nitrogen is composed of 30 to $50 \%$ of urea nitrogen, while the remaining is composed of creatinine, uric acid, amino acids, and ammonia, among others (Roseler et al., 1993; Broderick and Clayton, 1997).

Urea in milk is a byproduct of protein metabolism, since dietary protein digestion yields off ammonia, which is converted to urea in the liver, and then excreted from the body, primarily through urine (Mitchell et al., 2005). Since the urinary excretion of nitrogen and urea is linearly correlated with the plasma urea nitrogen (PUN) and MUN concentrations (Jonker et al., 1998; Kauffman and St-Pierre, 2001), MUN has been used as a tool to assess the herd nutritional status, and the excretion of nitrogen to the environment (Tamminga, 1992; Jonker et al., 1998; Schepers and Meijer, 1998; Jonker et al., 2002; Kohn et al., 2002).

Several methods have been devised to assess MUN levels in milk, including enzymatic and colorimetric methods. However, in the early 90's infrared spectroscopic analyses (IR) was introduced to estimate MUN levels. It was immediately introduced for DHI (Dairy Herd Improvement) programs, and became a quick and inexpensive method to measure urea levels in milk (Godden et al., 2001; Baumgartner et al., 2003; Hering et al., 2008). With the advent of the FTIR technique, urea determination based on the mathematical model of broad-spectrum (PLS) became more flexible (Delta Instruments, 2007).

However, due to the variability of milk composition, it is necessary to investigate precision parameters for application in different regions under diverse circumstances. Among these are the parameters of repeatability ( $r$ ) and reproducibility (R), and their limits (IDF, 1999).

The objective of this study was to evaluate CombiScope FTIR equipment based on the Fourier Transform Infrared Spectroscopy methodology (FTIR) to assess the level of milk urea nitrogen (MUN) in Brazil and its stability during storage.

\section{MATERIALS AND METHODS}

Raw milk samples were obtained from bulk tanks of dairy farms in Minas Gerais State, Brazil. To estimate MUN stability in milk during storage time, at different temperatures, the samples were collected as pools from at least eight cows from an experimental farm (School of Veterinary Medicine, Universidade Federal de Minas Gerais, Minas Gerais, Brazil).

The samples were collected in vials containing bronopol tablet (2-bromo-2-nitro-propane-1,3 diol: 6mg/tablet: D\&F Control, San Ramone, CA) as preservative, and kept under refrigeration at temperatures not exceeding $4^{\circ} \mathrm{C}$, and without freezing (IDF, 1995) during transportation to the laboratory. These samples were used for milk composition (FTIR), and somatic cell count (SCC) analyses with CombiScope FTIR. Another set of samples was collected in sterilized vials containing azidiol tablet $(4.79 \mathrm{mg}$ of sodium azide and $0.2 \mathrm{mg}$ of chloramphenicol/tablet: BS Pharma, Belo Horizonte, BR) as a preservative, and used for total bacterial count (TBC) by flow cytometry (Bactocount IBC 150, Bentley Instruments Inc., USA) (Bentley Instruments, 2002).

Homogenization and calibration checks on the CombiScope FTIR equipment were done daily before the analyses, using 12 standard samples of raw milk with different composition ranges of urea. The calibration was done using the multivariate calibration equation for the measurement of Non Protein Nitrogen (NPN) previously established in the equipment as NPNcalculated urea (Delta Instruments, 2007). Samples standard were provided by the DQCI Services (Mounds View, MN, USA).

Repeatability limit (r) for a confidence level of 95\% was evaluated according to the following equation (Nascimento et al., 2008).

$$
\begin{gathered}
\mathrm{r}=2.8 . \mathrm{Sr} \text { (equation } 1 \text { ) } \\
\text { where: } \mathrm{Sr}=\text { standard deviation of repeatability }
\end{gathered}
$$

The repeatability of the analysis of MUN content in raw milk with FTIR equipment CombiScope was determined using 200 samples, added with bronopol preservative, and obtained from bulk tank milk. Each ten samples were mixed together as a pool, totalizing 20 pools. Each pool was split into ten vials, and each vial was distributed in a different rack (Figure 1). 


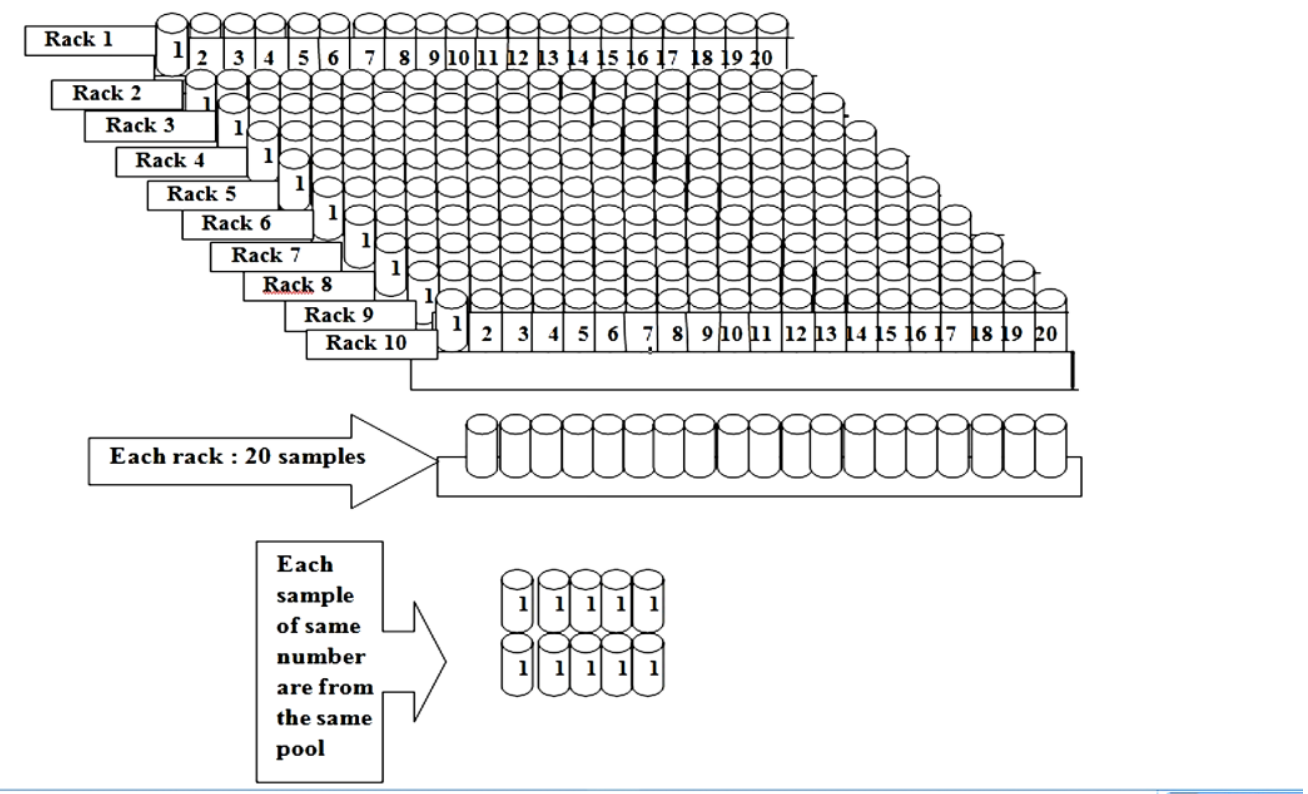

Figure 1. Layout of the repeatability in the FTIR method.

The samples were evaluated for somatic cell count, protein, fat, lactose, non-fat solids and MUN content (Godden et al., 2000; Arunvipas et al., 2003; Nascimento et al., 2008).

From the standard deviation obtained under reproducibility conditions, reproducibility variance $\left(\mathrm{SR}^{2}\right)$ associated with the results, and the " $R$ " reproducibility limit according to equation 2 were calculated (Eurachem, 1998; INMETRO, 2002; Nascimento et al., 2008).

$$
\mathrm{R}=2.8 \sqrt{ } \mathrm{SR}^{2} \text { (equation 2) }
$$

The reproducibility of the analysis of MUN content in milk with CombiScope FTIR was determined using 200 samples of raw milk from batches of raw milk routine samples, randomly chosen. During 10 days, a set of 20 samples of raw milk preserved with bronopol were collected each day, and each sample was divided into two subsamples. The first subsample was analyzed in the morning and the second one in the evening.

To evaluate MUN composition in raw milk from Minas Gerais State, Brazil, 554 samples of bulk tank milk, corresponding to 554 farms, were collected and each sample split into two aliquots, and analyzed with CombiScope FTIR, and ChemSpec 150 Analyzer (Bentley Instruments
Inc., USA). The milk components were analyzed with FTIR.

Additionally, extraneous urea (Sigma) was added to the raw milk, simulating a fraudulent practice, and simultaneously analyzed with CombiScope FTIR and ChemSpec 150 Analyzer. A total of 60 raw milk samples were split into three subsamples each, respectively, without any urea addition, and an addition of $20 \mathrm{mg}$ and $40 \mathrm{mg}$ of urea in $100 \mathrm{~g}$ of milk.

For an estimative of MUN stability in milk, five raw milk samples (three liters each) were divided into $50 \mathrm{~mL}$ vials, preserved with bronopol, and each sub-sample was stored at $4^{\circ} \mathrm{C}$, and $20^{\circ} \mathrm{C}$ during $0,1,3,5,7,10$ and 15 days. Milk composition, SCC, and $\mathrm{pH}$ were analyzed. For TBC, the same procedure was adopted, with azidiol as preservative.

The General Linear Model was used to compare different treatments. For pairwise comparison of means, the Tukey test was used for coefficient of variation (CV) below 15\%, and Student t test for CV values between $15 \%$ and $30 \%$ (Kuehl, 2000). The normal distribution of the responses was also observed (Oltner and Sjaunja, 1982). The statistical programs used were Minitab 15.0 for Windows (Minitab..., 2009), and SAS (Statistical..., 1992). 


\section{RESULTS AND DISCUSSION}

The repeatability of the analysis of urea in milk (MUN) with FTIR presented an average of $10.22 \mathrm{mg} / \mathrm{dL}$, standard deviation of $0.67 \mathrm{mg} / \mathrm{dL}$, coefficient of variation of $6.58 \%$ and repeatability limit $(\mathrm{Sr})$ of 1.87 . The results showed a good repeatability precision with CombiScope FTIR equipment for milk urea nitrogen (MUN).

In a study with UHT milk by Godden et al. (2000), 55 identical samples from individual cows were analyzed over a period of 14 days. The average concentration and standard deviation of urea in milk (MU) were, respectively, $6.52 \mathrm{mmol} / \mathrm{L}$, and $0.23 \mathrm{mmol} / \mathrm{L}$. The coefficient of variation was $3.44 \%$ and the limit of repeatability was 2.18 . In a second study 24 sets of replicas of milk samples were analyzed by Fossomatic 4000 Milk Analyser (Foss North America, Brampton, $\mathrm{ON}$ ) in a single day, and the mean, standard deviation, minimum and maximum concentrations of urea in milk (MU) were, respectively, $5.52 \mathrm{mmol} / \mathrm{L}, 0.78 \mathrm{mmol} / \mathrm{L}$, $4.57 \mathrm{mmol} / \mathrm{L}$ and $7.96 \mathrm{mmol} / \mathrm{L}$.
For the current experiment the reproducibility limit (R) for the determination of MUN in raw milk was $7.18 \mathrm{mg} / \mathrm{dL}$, calculated in a confidence level of 95\% (IDF, 1999), the average was $9.64 \mathrm{mg} / \mathrm{dL}$, the standard deviation of $0.56 \mathrm{mg} / \mathrm{dL}$, and the coefficient of variation of $5.86 \%$.

There was no significant difference between the enzymatic and the FTIR methods. The average concentration of MUN for FTIR was $9.84 \mathrm{mg} / \mathrm{dL}$, while for the enzymatic method it was $9.47 \mathrm{mg} / \mathrm{dL}$. Standard deviation and coefficient of variation $(\mathrm{CV})$ were respectively, $3.13 \mathrm{mg} / \mathrm{dL}$, and $31.81 \%$ for FTIR, and $4.11 \mathrm{mg} / \mathrm{dL}$, and $43.37 \%$ for ChemSpec (Table 1). The average difference between the equipment was $0.44 \mathrm{mg} / \mathrm{dL}$. The high CV is not related to the equipment, but to the variability of samples and MUN levels range, which were obtained from different regions and farms of Minas Gerais State, Brazil. The reliability of the Infrared equipment was good when compared to the enzymatic method, with a correlation coefficient (r) of $0.89(\mathrm{P}<0.0001)$. Results of MUN in milk with the enzymatic method and FTIR are shown in Figure 2. The results were consistent with the standards established for good quality samples.

Table 1. Comparison of mean, standard deviation (SD) and coefficient of variation (CV) for MUN levels in raw milk analyzed with FTIR and ChemSpec equipment

\begin{tabular}{lcccc}
\hline Equipment & Mean & $\begin{array}{c}\text { Standard Deviation } \\
(\mathrm{SD})\end{array}$ & $\begin{array}{c}\text { Coefficient of } \\
\text { variation }(\mathrm{CV}) \%\end{array}$ & $\mathrm{~N}$ \\
\hline CombiScope-FTIR & $9.84 \mathrm{a}$ & 3.13 & 31.81 & 554 \\
ChemSpec & $9.47 \mathrm{a}$ & 4.11 & 43.37 & 554 \\
\hline
\end{tabular}

Means followed by same letter indicate no statistical difference $(\mathrm{P}>0.05)$ by Student's $\mathrm{t}$ test.

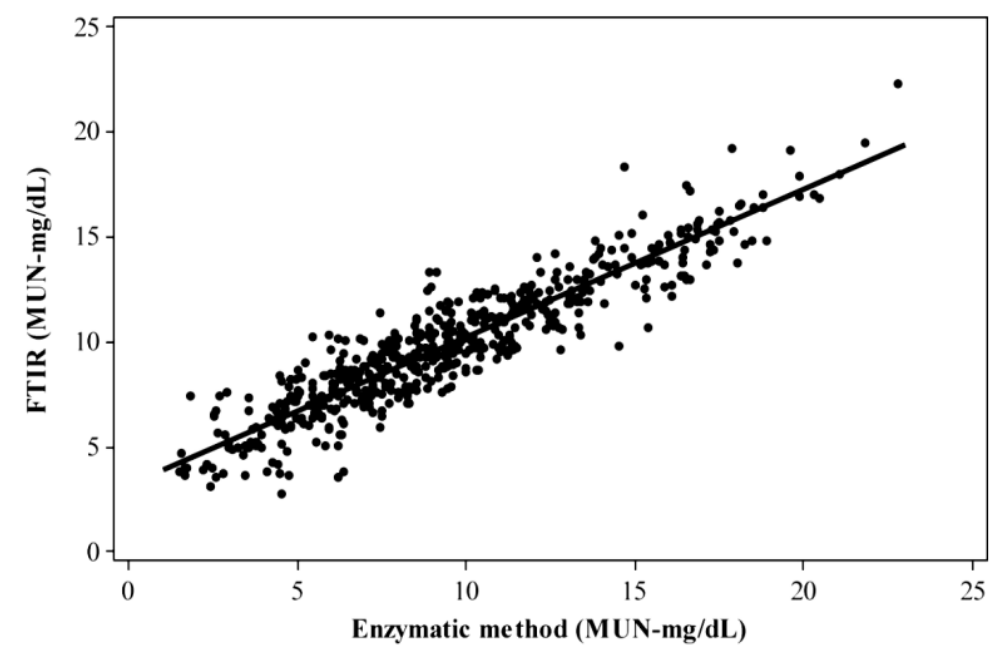

Figure 2. Scatterplot of milk urea nitrogen (MUN) results $(\mathrm{mg} / \mathrm{dL})$ through the enzymatic method $($ ChemSpec) and FTIR method (CombiScope FTIR) $(n=554)$. 
In a similar study the averages and distributions of MU for 89 herd milk samples analyzed were similar for the Fossomatic 4000 Milk Analyzer (mean $=4.11 \mathrm{mmol} / \mathrm{L}, \quad$ minimum $=1.61$, maximum $=6.79)$, and the Eurochem equipment $($ mean $=4.24 \mathrm{mmol} / \mathrm{L}, \quad$ minimum $=2.00$, maximum $=7.92$ ). The mean difference between both equipment was $0.13 \mathrm{mmol} / \mathrm{L}$ of $\mathrm{MU}$ in milk $(\mathrm{SD}=0.55 \mathrm{mmol} / \mathrm{L})$. There was equivalence between the Fossomatic 4000 Milk Analyzer equipment, an IR method, and the Eurochem test, an accepted enzymatic method of reference, with respectively, $4.85 \%$ and $2.65 \%$ of CV (Godden et al., 2000).

FTIR results for MUN in milk samples added with extraneous urea were lower than expected only at levels of 40mg/100g $(\mathrm{P}<0.05)$ (Table 2). Figure 3 shows the comparison of means and standard deviations (SD) for urea added to the milk at levels of 0,20 and $40 \mathrm{mg} / 100 \mathrm{~g}$. However, there was no significant difference in the levels of protein readings by FTIR equipment after urea addition to the milk. However, Hering et al.
(2008) found no difference between FT-MIR readings and other methods after the addition of urea at levels of 10,20 , and $30 \mathrm{mg} / \mathrm{dL}$ to ten samples of milk. FT-MIR presented good accuracy in the determination of extraneous urea (from 69.5 to $95.0 \%$ ), and reliability compared to other methods (correlations of 0.981 to 0.994 , $\mathrm{P}<0.001)$.

Regression analysis was performed using average results of MUN at temperatures of $4^{\circ} \mathrm{C}$ and $20^{\circ} \mathrm{C}$ for days $0,1,3,5,7,10$, and 15 . MUN concentration was constant during the storage at $4^{\circ} \mathrm{C}$ for up to 15 days, contrary to some studies which reported MUN levels increase for milk stored under refrigeration for more than 7 days (Oltner and Sjaunja, 1982; Miettinem and Juvonen, 1990; Carlsson and Bergstrom, 1994; Eicher et al., 1999; Godden et al., 2000). Nevertheless, after storage at $20^{\circ} \mathrm{C}$ during three days, increasing MUN levels were observed, maybe related to a possible microbial degradation of protein.

Table 2. Comparison of mean and standard deviation (SD) in the analysis of urea (MUN), after the urea addition in milk by ChemSpec and FTIR equipment

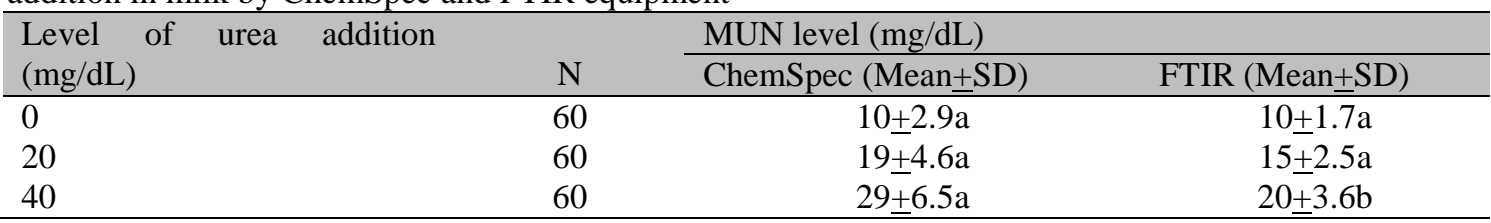

Means followed by different letters indicate statistically significant differences $(\mathrm{p}<0.05)$ by Student's $\mathrm{t}$ test.

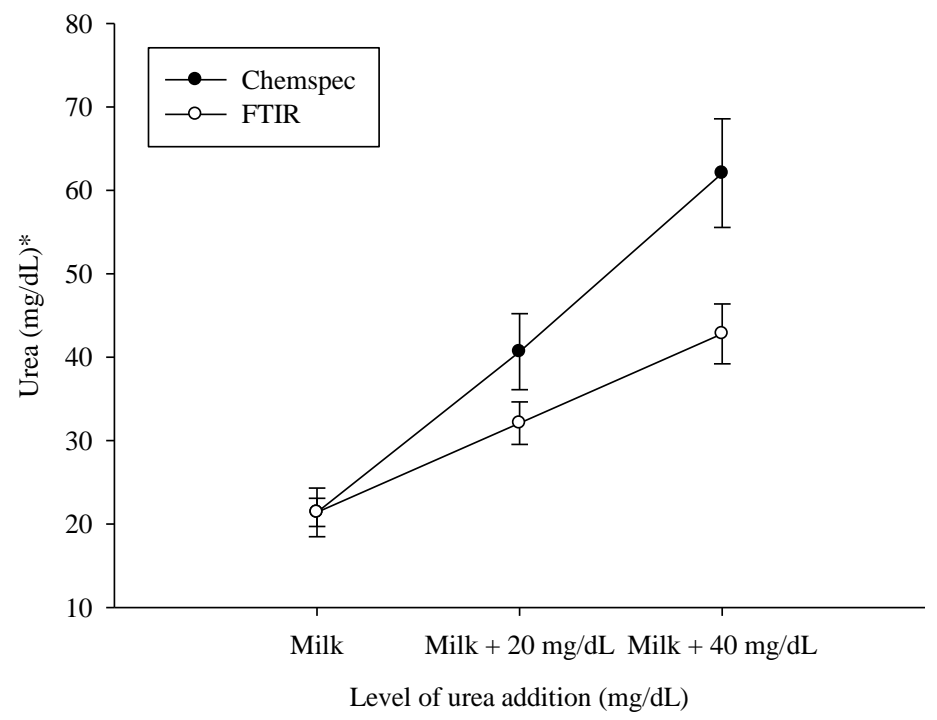

Figure 3. Urea concentration in milk, and after addition of extraneous urea at levels of $20 \mathrm{mg} / \mathrm{dL}$, and $40 \mathrm{mg} / \mathrm{dL}(\mathrm{n}=60)$ analyzed by ChemSpec and FTIR equipment. *Urea levels obtained from MUN x 2.14. 


\section{CONCLUSIONS}

The CombiScope FTIR equipment showed good precision and accuracy in repeatability and reproducibility for the measurement of raw milk urea nitrogen (MUN). MUN levels in milk stored under refrigeration remained constant for up to two weeks. FTIR equipment failed to detect extraneous urea added to the milk at levels of $40 \mathrm{mg} / 100 \mathrm{~g}$. However, protein levels measured by FTIR were not affected by added urea.

\section{ACKNOWLEDGEMENTS}

FAPEMIG, CNPq (Proj. 578736/2008-0), Laboratório de Análise da Qualidade do LeiteUFMG/FUNDEP, CAPES.

\section{REFERENCES}

ARUNVIPAS, P.; VANLEEUWEN, J.; DOHOO, I.; KEEFE, G.P. Evaluation of the reliability and repeatability of automated milk urea nitrogen testing. Short Communication. Can. J. Vet. Res., v.63, p.67-60, 2003.

BAUMGARTNER, M.; FLÖCK, M.; WINTER, P. et al. Evaluation of Fourier Transform Infrared Spectrometry for the routine determination of urea in milk. Milchwissenschaft, v.58, p.599-602, 2003.

BENTLEY INSTRUMENTS INC. Bactocount 150 operator's manual. Chaska: Bentley Instruments Inc., 2002. 49p.

BRODERICK, G.A.; CLAYTON, M.K. A statistical evaluation of animal and nutritional factors influencing concentration of milk urea nitrogen. J. Dairy Sci., v.80, p.2964-2971, 1997.

CARLSSON, J.; BERGSTRÖM, J. The diurnal variation of urea in cow's milk and how milk fat content, storage and preservation affects analysis by a flow injection technique. Acta Vet. Scand., v.35, p.67-77, 1994.

DELTA INSTRUMENTS, An Advanced Instruments Company. LactoScope FTIR user's guide. Milk and Liquid Dairy Product Analyzer. Netherlands: Delta Instruments, 2007. 138p.
EICHER, R.; BOUCHARD, E.; TREMBLAY, A. Cow level sampling factors affecting analysis and interpretation of milk urea concentrations in 2 dairy herds. Can. Vet. J., v.40, p.487-492, 1999.

EURACHEM. The Fitness for Purpose of Analytical Methods: A Laboratory Guide to Method Validation and Related Topics. London: LGC Communications, 1998. 61p.

GODDEN, S.M.; LISSEMORE, K.D; KELTON, D.F. et al. Analytic validation of an infrared milk urea assay and effects of sample acquisition factors on milk urea results. J. Dairy Sci., v.83, p.435-442, 2000.

GODDEN, S.M.; LISSEMORE, K.D; KELTON, D.F. et al. Factors Associated with Milk Urea Concentrations in Ontario Dairy Cows. J. Dairy Sci., v.84, p.107-114, 2001.

HERING, P.; HANUŠ, O.; FRELICH, J. et al. Relationships between the results of various methods of urea analysis in native and enriched milk. Czech J. Animal Sci., v.53, p.64-76, 2008.

IDF. International IDF Standard 50C:1995: Milk and milk products - guidance on sampling. Bruxelas, 1995.

IDF. International IDF Standard 128A:1999: Milk - definition and evaluation of the overall accuracy of indirect methods of milk analysis. Aplication to calibration procedure and quality control in the dairy laboratory. Bruxelas, 1999.

INMETRO. Instituto Nacional de Metrologia, Normalização e Qualidade Industrial. Orientação sobre Validação de Métodos de Ensaios Químicos. Duque de Caxias, DOQ-CGCRE-008, 2003.

JONKER, J.S.; KOHN, R.A.; ERDMAN, R.A. Using milk urea nitrogen to predict nitrogen excretion and utilization efficiency in lactating dairy cows. J. Dairy Sci., v.81, p.2681-2692, 1998.

JONKER, J.S.; KOHN, R.A.; HIGH, J. Use of milk urea nitrogen to improve dairy cow diets. $J$. Dairy Sci., v.85, p.939-946, 2002.

KAUFFMAN, A.J.; ST-PIERRE, N.R. The relationship of milk urea nitrogen to urine nitrogen excretion in Holstein and Jersey cows. J. Dairy Sci., v.84, p.2284-2294, 2001. 
KOHN, R.A.; KALSCHEUR, K.F.; RUSSEKCOHEN, E. Evaluation of models to estimate urinary nitrogen and expected milk urea nitrogen. J. Dairy Sci., v.85, p.227-233, 2002.

KUEHL, R.O. Design of experiments: statistical principles of research design and analysis. 2nd ed. Pacific Grove: Duxbury. 2000. 666p.

MITCHELL, R.G.; ROGERS, G.W.; DECHOW, C.D. et al. Milk Urea Nitrogen Concentration: Heritability and Genetic Correlations with Reproductive Performance and Disease. J. Dairy Sci., v.88, p.4434-4440, 2005.

MIETTINEN, P.V.A; JUVONEN, R.O. Diurnal variations of serum and milk urea levels in dairy cows. Acta Agric. Scand., v.40, p.289-294, 1990.

MINITAB Inc.: MINITAB statistical software, releases 15 for Windows, State College, PA. 2009.

NASCIMENTO, A.R.; ZIOLLI, R.L.; ARARUN Jr., J.T. et al. Avaliação do desempenho analítico do método de determinação de TPH (Total
Petroleum Hydrocarbon) por detecção no infravermelho. Eclet. Quim., v.33, p.35-42, 2008.

OLTNER, R.; SJAUNJA, L.O. Evaluation of a rapid method for the determination of urea in cow's milk. Acta Vet. Scand., v.23, p.39-45, 1982.

ROSELER, D.K.; FERGUSON, J.D.; SNIFFEN, C.J.; HERREMA, J. Dietary protein degradability effects on plasma and milk urea nitrogen and milk non-protein nitrogen in Holstein cows. $J$. Dairy Sci., v,76, p.525-534, 1993.

SCHEPERS, A.J.; MEIJER, R.G.M. Evaluation of the utilization of dietary nitrogen by dairy cows based on urea concentration in milk. $J$. Dairy Sci., v.81, p.579-584, 1998.

STATISTICAL Analisys Sistem-SAS. 1992. SAS technical report P-229. SAS/STAT Software: Changes and enhancements, release 6.07. Cary, NC.

TAMMINGA, S. Nutrition management of dairy cows as a contribution to pollution control. $J$. Dairy Sci., v.75, p.345-357, 1992. 